\title{
Research on Translation Strategies of Advertisement from the Perspective of Functional Equivalence
}

\author{
Juan Lu \\ School of Foreign Studies, Shaanxi Sci-Tech University, HanZhong 723000, Shaanxi, China
}

672241343@qq.com

Keywords: Pun translation; Expansion translation; Borrowing; Reversion

\begin{abstract}
As a product of modern society, the advertisements have been involved in all industries. Therefore, the ad and its translation are given more priority. However, the difference between Chinese and English in language and culture indicates that the advertisement translation is a flexible and complex work. This paper aims to study the translation strategies of advertisement from the functional equivalence, which has great significance to advertisement translation.
\end{abstract}

\section{Introduction}

With the trend of globalization, corporations cannot operate well only with the good quality and service. The advertisement propaganda is essential to form the special characteristics of its brand. Advertisement is an important means for promoting merchandise and the slogan across borders is used frequently. Excellent advertisements for the product can be icing on the cake, while mediocre slogan makes products eclipsed. The translation of advertisement is a multi-language and multi-cultural translation whose quality can directly affect the effectiveness of the publicity and promotion of the advertising. Nowadays, China has joined the WTO, more international economic activities followed. Exploring translation work of advertisement has more theoretical and practical significance for the future of the enterprise and the state. Due to the difference of culture, translators are asked to translate flexibly and creatively rather than being highly loyal to the original to make the version of advertisement is consistent with the stylistic feature of target language and make the target audience like and accept the commodity, which is aim to propagate the merchandise, promote economic trade and enhance cultural exchange [1].

\section{Functional Equivalence Theory}

Functional equivalence translation consists in reproducing in the receptor language the closest natural equivalent of the source language message, first in terms of meaning and second in term of style [2]. Nida's definition of translation from a functional point of view has three advantages. First, it shows what you translate. It is obviously information, focusing on the content, and then the content; second, it shows that due to the language and culture difference the original language and translated language can be equivalent relatively; finally, it takes into account the acceptability of translation. The equivalence in this theory including four aspects-- (1) vocabulary equivalence; (2) syntactic equivalence; (3) text equivalence; (4) style equivalence. Therefore, in literary translation, according to Nida's theory, the translator following these four functional equivalence principles accurately reproduces the source language and its cultural connotations. Compared with the previous translation theory, the difference of functional equivalence lies in the fact that it will be accepted into the research field of linguistics, cultural and readers' reflection included. Functional equivalence theory is based on meaning and style peer, emphasizing the target language readers' reflection is similar with the original readers'. Readers' objective reflection to the translation product is as a measure of quality standards [3].

\section{Translation Strategies of Advertisement under Functional Equivalence}

Advertising language is a very special language, they are usually informative, persuasive and 
expressive. The use of rhetorical devices is also unique, which makes people understand the wisdom from humor, and the magic from wateriness [4].

Personification. Advertising products are personified, given human emotion, thought and image, which makes readers feel that it is like talking with old friends. Adopting personification in advertisement not only focuses on the function and feature of the product but also enhances the readability of the advertisement.

E.g.1. Passion lives here.-激情在这里燃烧

This is the slogan of the 20th Winter Olympics in Turin in 2006. It is the successful example of advertisement using the personification which appeared in all the booths of Turin Olympics, publications, promotional activities, and the department of communication, all competition venues and facilities. 'Fashion lives here' expresses the value and sprite of the winter Olympics concisely and shows the high enthusiasm of Italians to any action. As the theme slogan, passion itself cannot use 'lives', while advertisement manufacturer adopts personification to make people full of imagination. The passion, Italian passion is here-in each corner of the winter Olympic in Turin.

E.g.2. 君家发达, 发达进家; 发达电器, 伴君发达-You advance, advance with you .Advance with you, we advance.

In personification, 'you' is used frequently. Its usage will make consumers be closely to the product as human, even a friend. The version uses the personification. In addition, the beginning 'you advance' and the end of 'we advance' is antithesis, which enhances the sense of rhythm and reads softly. The repetition of 'you' which is personified emphasizes that the product is what consumers are interested in and are most likely to want. What's more its usage is easy to arouse the resonance of consumers and shorten the consumers' distance from the product. The translation is more possible to promote the product and reach the effect similar with the original.

E.g.3. 穿上“金鞋”，足下生辉-Golden shine, shines your way.

'Golden shines' is personification. The original focuses on the importance and function of the shoes, while the focus in translation converses in the aspect of consumers, emphasizing that you will benefit from owning this product.

In the translation of advertisement, the expression of affection is vial. The translation is not only used to appreciate, the most important is to motivate the purchasing desire of consumers and their final purchasing behavior. Therefore, the statement equivalence in the translation of advertisement is not enough. The translator should pay more affection into the lifeless product to make the target group arouse their own affection for the product and have a good impression on the product. To reach this goal, translators tend to adopt the personification, especially using 'you'. Personification is more easily to shorten the distance between commodity and consumers. Consumers feel approachable when watching the advertisement and urge their consuming. The adoption of personification is a proper method to realize the functional equivalence. It aims at the propaganda of products, ignoring the loyalty for the style and sentence structure of the original, which is consistent with the original in functions [5].

Pun Translation. In the translation of advertisement, some translators give priority to the creation. The adoption of pun takes advantage of the double meaning to produce two different expressions meaning in the advertisement to attract consumers. For example:

E.g.1. Make your every hello a real good-buy. (Ad for Telecom Company)

The pronunciation of good-buy and good-bye is similar. 'good-buy' is a means of promoting the Telecom product or service, which gives caller a deep appealing, while 'good-bye' responds to 'hello'. With this translation may leave customers a good impression that the Telecom company provides a good service. And they are homophonic pun. The meaning is that the clear call from beginning greeting hello to the end good-buy is the high-level service for customers. It also means the price of the call is valuable and it's 'a real good-buy'.

E.g.2. I am more satisfied. Ask for More (Ad for More cigarettes)

The translation uses two puns with the word 'more'. 'More' has two meanings. One is as an adverb. In this advertisement, it is a comparative form of 'satisfied'. However, after capitalized, it becomes the brand of cigarettes product. This advertisement is easy to be remembered and may let 
consumers think that this product is superior to others not only in quality but also in taste and can make consumers more satisfied. The pun is divided into two aspects and expressed in translation respectively, which is more attractive for consumer and more persuasive..

E.g.3. The Unique Spirit of Canada: We Bottled It. (加拿大独特的民族精神，我们身上集中体 现; 加拿大独特风味的酒, 我们为您瓶装奉献。)

It is the headline of the advertisement for Whisky. Spirit not only means the vigor but also means the taste of whisky. The advertisement can be understood as the ethnic spirit of Canada and the special taste of whisky. In addition, bottle can be concentration and jug, which conveys the double meanings of the original better. In this translation, the translator digs two meanings hidden in the original. On one hand, 'spirit' stands for the vigor of Canadian, which leaves consumers a good impression on Canada. On the other hand, it stands for the taste of whisky, which with the bottled package attracts consumers a lot.

The examples with pun translation can be seen as follows: Your everyday life's so very busy. But our Long Card can make it easy. (衣食住行, 有龙则灵); Midea products are beautiful, beautiful from top to toe, beautiful inside out.(美的家电,美的全面,美的彻底); Try our sweet com, you'll smile from ear to ear (ad for com). (尝一尝甜玉米! 您会胃口大开,笑口常开)

It is the advertisement for Construction Bank of China in the first one. It adopts the saying-waters gains miraculous for residing dragons. Long is a pun. When translating long card, translator imitates the united wording of MasterCard, and makes long into italic to distinguish from the English word 'long'. Long Card is translated to stand for the referential meaning and symbolic meaning. In the original ad for Medea, 'mei' is used three times in the second one. But the English name of this brand is Midea, which is nothing with beauty. It is difficult for translator to combine pronunciation with meaning. Translating 'Mei' into 'beautiful' not only conveys the meaning of the original but also reflects the form of it. It is a successful advertisement for corn in third one. The ad uses 'ear' not only to mean the organ of people also suggest the aspect of the corn- ear of corn head. Thus 'from ear to ear' has a double content-one another corn and smile. With this content, the ad manufacturer describes the people's love for this kind of corn. The translation reproduces the context of the pun in the original [6].

Expansion Translation. The expansion method aimed at the clear expression of the advertising. Through digging the hidden information of the original or making up for the essential information, the translation can get the effect of propaganda. For example, 海尔电器, 三包承诺- We offer 3- R guarantee, namely guaranteed repair, replacement and refund; 三联运输公司: 海陆空联运Sanlian Shipping Service SSS: Sea- borne, Air borne and Land- surface Transportation. Both 3-R and SSS is the concentrated expression that is concise in expression but rich in content. Therefore, it can be accepted by the public and be used in advertising. However, if the target audience is in foreign countries, the version must supplement the meaning of 3-R and SSS.

E.g.1. 默默无“蚊”- Mosquito repellent incense, repelling Mosquitoes in silence.

The original advertisement uses the same pronunciation 'wen', which can only be understood by Chinese. For promoting the Mosquito to foreign audience, the expansion translation is essential. Firstly, the translator introduces the product-Mosquito and then introduces the effect of Mosquito-no mosquito will disturb you. With the expression of no Mosquito, the advertisement shows the satisfaction of consumers and the benefits the product brings them. The version adopts the rhetoric to annotate 'incense' and 'silence', showing the pragmatic function and purpose function.

E.g.2. A Mars a day keeps you work, rest and play. (一日一块Mars 巧克力, 保您工作、休 息、娱乐随心意)

From the ad E.g.2, it seems lack of persuasive function. However, the usage of vivid language arouses people's memory both in form and in content. People may think of two English idioms- 'An apple a day keeps the doctor away.' and 'all work no play makes Jack a dull boy.' Eating a piece of Mars seems to be healthier and cleverer. In the original, the target audience may not understand how a Mars will keep you work, rest and play, while in the translation, the translator adds 'suixinyi' 
to be understood easily. In addition, day and play is in rhyme. So the version is. It reproduces the style of the original.

E.g.3. Not all cars are created equal.-Ad for Mitsubishi Motors（人人生而平等, 汽车却有优劣 之分）

Mitsubishi Motors design the ad E.g.3 for the American market. It imitates the sentence 'all men are created equal' in 'Declaration of Independence' on purpose. What's more, Mitsubishi changes the Affirmative sentence into negative sentence to show its difference and can be accepted easily. However, it is not acceptable by Chinese consumer due to the cultural difference. The version in E.g.3 adds the information, which is consistent with the psychology of Chinese audience. Then the functional equivalence in meaning and style will be reached [7].

Borrowing. The borrowing method adopted in the advertisement translation refers to borrowing from the expression or structures in the target language including proverb, poetry or idiom, which are all familiar for the target audiences so that the advertisement for the products can reach the goal of promoting. For example,

E.g.1. 随身携带, 有备无患; 随身携带, 有惊无险。(Ad for heart pill)-A friend in need is a friend indeed.

The creator of the original of advertisement is wise, especially using the repetition and thimble to make the structure simple and rhyming, which reaches the goal of emphasizing the quality and effectiveness of heart pill. The structure of translation borrowing the proverb-A friend in need is a friend indeed is concise. It is much easier to draw audience attention. The repetition and personification are consistent with the thesis of the original. The word friend brings energy, friendship and trust to advertisement audience, which shortens the distance between product and customers.

The same function of the borrowing translation can be showed from the following examples. Where there's a road, there's a Toyota! If translated as a version '哪里有路, 哪里就有丰田车', the version will express the meaning and be easy to understand. However, the version adopts the proverb 'Car to Piedmont Road, the boat to cross the bridge' and makes the advertisement more persuasive and appealing. East, west, Hangtian is best.-Ad for Hangtian car (城乡路万千, 路路有 航天) Borrowed from the quotes of George Orwell, a British poet, 'East, west, home is best', the translation version reflects the wording characteristics of conciseness and neat antithesis and realizes the equivalence of meaning and style.

The borrowing method adopts the proverbs, idioms or traditional stories the target audience are familiar with and create the new expression style, which makes the target audience understand the advertisement easily. Using these languages full of humor is helpful to overcome the tackle of language and culture to cause the resonance of target audience. On the other hand, translating advertisement copes with the original and avoids the errors in structure and grammar [8].

\section{Conclusions}

In conclusion, the high-quality advertisement is not only helpful for the purchasing of the products by consumers, but also a masterpiece will be remembered in audiences' hearts. In the condition of promoting, the translation of advertisement should get this effect. The translation of English advertising is by no means the machine translating activity from one language to another. It should not be faithful and equivalent in common sense while it is a multi-cultural communication [9]. Therefore, the advertisement translation should regard its function and purpose as center, version reader as goal, target language and culture as tendency to overcome the gap of multi-culture and choose the proper strategies of translation to reproduce and realize the equivalence in meaning, pragmatic, and society culture. In target language, reach the informative, persuasive, and expressive functions, and promote the merchandise in translated context. 'Pursuing the similar feeling between the readers of the original and the translation' and reproducing the persuasive and informative function in the target language culture to reach the propaganda effect of promoting products in the translating context. The functional equivalence theory requires that the translator should study the 
difference of the language, culture, psychology of consumer of the target language and be based on similar function and efficiency [10]. Then using effective translation strategies to reach the functional equivalence and cope with the tastes and psychology of consumers.

\section{References}

[1] Peter Newmark. Approaches to Translation [M]. Shanghai, Shanghai Foreign Language Education Press, 2001.

[2] Alexander Fraster Tytler, Essay on the Principles of Translation [M]. Amsterdam, John Benjamins B. V., 1978.

[3] Baker, M. In Other Words: A Coursebook on Translation [M]. London, Routledge, 1992.

[4] Nida Eugene A. Toward a Science of Translating [M]. Holland, Brill, 1994.

[5] Catford, J. C. A Linguistic Theory of Translation: An Essay on Applied Linguistics [M]. Oxford, Oxford University Press, 1965.

[6] Joel F. Sherzer. Speech Play and Verbal Art [M]. Texas, University of Texas Press. 2002.

[7] Leech, G. N. English in Advertising [M]. London, Longman, 1996.

[8] Hatim, B. Communication Across Cultures [M]. Shanghai, Shanghai Foreign Language Education Press, 2001.

[9] Jin, D. \& Eugene A. Nida. On Translation [M]. Beijing, Beijing Foreign Translation Company, 1984.

[10]Nida, Eugene A \& Taber, C.R. The Theory and Practice of Translation [M]. Shanghai, Shanghai Foreign Language Education Press, 1989. 